\title{
Bacillus sphaericus and Bacillus thuringiensis to Insect Control: Process Development of Small Scale Production to Pilot-Plant-Fermenters
}

\author{
Christine Lamenha Luna-Finkler and Leandro Finkler \\ Federal University of Pernambuco \\ Brasil
}

\section{Introduction}

Bacteria from the genus Bacillus are among the entomopathogenic microorganisms most commonly used as biocontrol agents. Among them, Bacillus sphaericus (Bs) and Bacillus thuringiensis $(\mathrm{Bt})$ are used in vector control programs of endemic diseases such as dengue, malaria and filariasis. Because they are spore-former bacteria and produce toxins highly specific to target insects are better suited to industrial production and field application.

Development of microbial insecticides production technology depends basically of four steps: i) isolation and selection of strains with higher activity, ii) fermentation process optimization using cheap raw materials, iii) application of an appropriate method to cell separation; iv) development of formulations.

The aims of this chapter are present a general overview of properties and applied use of these mosquitocidal bacteria and strategies or considerations to development a cost-effective process for success of its large scale production.

The chapter will be divided into 3 (three) stages:

- $\quad$ - Bacillus sphaericus and Bacillus thuringiensis in vector control: an overview

- $\quad$ - Stages of product development: storage and maintenance organisms, fermentation methods, solid-liquid separation techniques and formulations.

- $\quad$ - Process on a laboratory scale to pilot-plant-fermenters.

\section{Bacillus sphaericus and Bacillus thuringiensis in vector control: an overview}

The indiscriminate use of chemical pesticides and their harmful consequences to the environment encouraged the development of biological control techniques against harmful insects, both in agriculture and public health. Among the procedures used for integrated pest management, biological control techniques are frequently chosen by the advantages they offer, particularly specificity and safety for man.

Among the biological control agents, bacteria of the genus Bacillus are among the most widely used entomopathogenic microorganisms, especially for its ability to form spores and toxins highly specific to target insects. Bs and Bt are employed in programs to control larvae of important mosquito disease vectors such as filariasis, malaria and dengue. 
Bs was first discovered in 1904, but only in 1965 its activity against larvae of Culicidae was recognized. However, the strain discovered (B. sphaericus $\mathrm{K}$ ) did not have a very effective activity, which limited its use (Kellen et al., 1965). Currently, several toxic strains are known, and most studies utilize strains 1593 and 2362, respectively isolated in Indonesia (Singer, 1973) and Nigeria (Weiser, 1984). It has high specificity and toxicity against insects of the Order Diptera, especially of genus Culex and Anopheles. Because it is harmless to humans, animals and the environment, its use is recommended by the World Health Organization in public health programs.

Bs is a Gram-positive bacterium, strictly aerobic and is not able to use sugars as carbon sources and energy, requiring growth media containing proteins and ions $\mathrm{Ca}^{++}$and $\mathrm{Mg}^{++}$for sporulation (Russel et al., 1989). Present spherical, terminal or sub-terminal spores and swollen sporangia, and the most toxic strains produce a protein crystal in the form of parallelepiped composed of two proteins of 51 and $42 \mathrm{kDa}$. Both proteins are required for the toxic action, being synthesized in equimolar amounts during sporulation (Charles et al., 1997). After sporulation, the crystal remains associated to endospore, and this complex (endospore + crystal) is inside the exosporium.

After ingestion of the spore/crystal complex, proteins are solubilized in the larvae stomach by the combined action of proteases and alkaline $\mathrm{pH}$, causing damage to the nervous system and digestive tract, until the occurrence of sepsis. The period between ingestion of the toxin and lethality of larvae is up to 48 hours.

Bs is widely distributed throughout the environment and can be isolated from soil, aquatic ecosystems and in dead mosquito larvae. It has the ability to persist in aquatic environments, polluted or not (Baumann et al., 1991). This represents a great advantage when it is applied in environments containing large amounts of organic matter, providing a more durable control on larvae populations.

Bt was first isolated in Japan, when Ishawata described a spore-forming bacteria that caused mortality in larvae of the silkworm (Bombix mori). In 1911, Berliner reported the same type of bacteria acting on the flour moth (Anagasta kuhniella), and in 1915 named it Bacillus thuringiensis. The researcher said the presence of an inclusion body in spore, but not related to the insecticidal properties of the microorganism, mentioning the possibility of using it to control moths. Their use to control Lepidoptera was soon recognized, and in 1938 was marketed the first product based on this bacterium (Sporeine), effective against caterpillars of various vegetables and fruit (Dias, 1992).

Products development based on Bt has intensified in the 50's, but only in 1970 the strain B. thuringiensis var. kurstaki HD-1 has been produced commercially by many companies and agrochemical products of fermentation (Navon, 2000). Currently, these bacteria-based products account for about $90 \%$ of the worldwide market for biological control agents.

In 1977, Goldberg and Margalit (1977) identified a strain that showed toxic activity against Diptera. The strain was isolated in Israel from moribund larvae of Culex pipiens, being called B. thuringiensis var. israelensis (Bti), which is the first bacterium used in biological control programs against Diptera around the world. In Pasteur Institute this strain was identified as B. thuringiensis serotype H-14. It had high toxicity to larvae of mosquitoes of genus Aedes and Culex, and less active against Anopheles. It can be easily found in the environment and isolated from soil, warehouses, surface of leaves and insect habitat (Hongyu et al., 2000). It has aerobic metabolism, glucose is used as a source of carbon and energy, as well sucrose, Larabinose, D-xylose and D-mannitol. 
The safety of products based on Bt on non-target organisms has been extensively reviewed by several authors. It is completely harmless to humans and other mammals, as well as aquatic vertebrates, invertebrates and plants.

Insecticidal activity of most $\mathrm{Bt}$ subspecies is related to the production of a parasporal inclusion of the crystal structure called $\delta$-endotoxin, which is synthesized during sporulation and is located associated with the spore. The crystal structure is comprised of three distinct domains: Domain I (a 7 a-helical bundle) is equipped for pore formation in insect epithelial membrane; Domain II (a triple $\beta$-sheet structure) may be responsible for receptor recognition; Domain III (a $\beta$-sandwich region) may protect the toxin from further degradation during proteolytic processing (Honée and Visser, 1993; Vontersch et al., 1994).

Depending on the variety of species, the $\delta$-endotoxins are composed of different structures and molecular weights ranging between 27 and $160 \mathrm{kDa}$. These proteins (protoxins) are called Cry proteins and are identified according to their degree of toxicity to the various orders of insects susceptible. Table 1 shows examples of Cry proteins found in Bt, which can be divided on the basis of their activity into five major classes: i) Lepidopteran specific; ii) Lepidopteran and Coleopteran specific; iii) Coleopteran specific; iv) Dipteran specific; and v) Nematode specific (Cannon, 1996).

When larvae ingest these inclusions, protoxins are solubilized and converted into active toxins of low molecular weight by enzymes (proteases) in the larvae stomach at alkaline $\mathrm{pH}$. After binding to specific receptors, toxin rapidly enters in the plasma membrane of intestine cells, with formation of pores channels and the loss of membrane integrity. Such events lead to cell lysis and finally the death of the insect through starvation or septicemia (Kumar et al., 1996).

\begin{tabular}{|c|c|c|c|}
\hline Protein & Subclass & Protoxin $(\mathrm{kDa})$ & Target insect \\
\hline \multirow[t]{8}{*}{ CryI } & $\mathrm{IA}(\mathrm{a})$ & $130-160$ & Lepidopteran \\
\hline & $\mathrm{IA}(\mathrm{b})$ & $130-160$ & Lepidopteran/Dipteran \\
\hline & $\mathrm{IA}(\mathrm{c})$ & $130-160$ & Lepidopteran \\
\hline & IB & $130-160$ & Lepidopteran \\
\hline & IC & $130-160$ & Lepidopteran \\
\hline & ID & $130-160$ & Lepidopteran \\
\hline & IE & $130-160$ & Lepidopteran \\
\hline & IF & $130-160$ & Lepidopteran \\
\hline \multirow[t]{3}{*}{ CryII } & IIA & $70-71$ & Lepidopteran/Dipteran \\
\hline & IIB & $70-71$ & Lepidopteran \\
\hline & IIC & $70-71$ & Lepidopteran \\
\hline \multirow[t]{4}{*}{ CryIII } & IIIA & 73 & Coleopteran \\
\hline & IIIB & 73 & Coleopteran \\
\hline & IIIC & 73 & Coleopteran \\
\hline & IIID & 73 & Coleopteran \\
\hline \multirow[t]{5}{*}{ CryIV } & IVA & 134 & Dipteran \\
\hline & IVB & 128 & Mosquitoes \\
\hline & IVC & 58 & Blackflies \\
\hline & IVD & 72 & Nematodes \\
\hline & CytA & 27 & \\
\hline CryV & $\mathrm{V}$ & 81.2 & Lepitopteran/Coleopteran \\
\hline
\end{tabular}

Table 1. Cry proteins found in B. thuringiensis, molecular sizes and target insect (adapted from Rukmini et al., 2000). 


\section{Stages of product development}

\subsection{Storage and maintenance organisms}

Bacillus cultures should be kept in conditions which ensure their phenotypic and genotypic characteristics. In an industrial fermentation of Bacillus species, it is important to ensure the integrity of the strain, and the use of appropriate methods of culture preservation is fundamental to the development of bioprocess.

Not all species respond similarly to preservation methods, and its success depends on appropriate choice of medium, the culture procedures and storage time. Is recommended verify periodically the intactness of bacterial plasmid content in all steps of culture, because changes in the plasmid content could lead the production of non-active culture in industrial fermentation.

Some of the main methods for the preservation of Bacillus strains are strips of filter paper, periodic subcultures, mineral oil and freeze-drying.

\subsection{Fermentation methods}

Cultivation of entomopathogenic bacteria are carried out in batch or fed batch. In a typical batch fermentation process, cultures of $\mathrm{Bs}$ and $\mathrm{Bt}$ are characterized by the following morphological and physiological variations: a) Vegetative growth stage, with the occurrence of exponential phase, presence of isolated cells, in pairs and in chains, with uniform size and high mobility; b) Transition to sporulation, with decreased growth rate and presence of shorter and isolated cells without motility; c) Stage of sporulation; d) Stage of spore maturation and cell lysis. In Bt cultures is observed a linear growth phase after exponential growth phase, with rapid drop in $\mathrm{pH}$. In the stage of sporulation, there is a tendency to cells flocculation.

Proper choice of the medium ingredients is critical to success of commercial production, aiming to obtain a greater toxic activity per volume of fermentation broth. The medium selection depends on three factors: assimilation by the organism, availability and cost. To obtain large-scale bio-insecticides, the use of raw materials from industrial waste can reduce the costs of the fermentation process, but care should be taken into account the influence of media components on cell recovery and formulation of the final product.

The main components of culture media are carbon sources, nitrogen and trace elements. A large number of agro-products and waste could be used as substrates, for example, molasses, water washing and pressing of fruit and cereals, cheese whey, peptones and slaughterhouse waste, oil cakes, fish meal, among others (Dias, 1992). In a previous study (Luna et al., 2004), was evaluated use of supernatants obtained from the flocculation/sedimentation process to cell separation of B. thuringiensis var. israelensis - Bti, which were supplemented with original culture medium. Spores concentration of $1 \times 10^{10}$ $\mathrm{UFC} / \mathrm{mL}$ were obtained, demonstrating the viability to use the supernatant to formulation of the culture medium.

Bs does not use carbohydrates as carbon source, and media should be formulated based on protein components. The choice of substrates for Bti cultivation is simpler because it consumes sugars, amino acids and proteins. Glucose, starch and molasses are the carbon sources most commonly used. Medium for the cultivation of this bacterium must be formulated properly on the concentration of sugar, because the use of high levels of this substrate without the appropriate adjustment in the concentration of nitrogen source could cause a drop in $\mathrm{pH}$ values between 5.6 and 58 , which could lead to inhibition of sporulation. 
The main parameters monitored during the fermentation process are temperature, dissolved oxygen, $\mathrm{pH}$ and sugar concentration. Due to the large consumption of oxygen during the cultivation, control of this parameter is very important and should not reach values below $20 \%$ (Couch, 2000).

Controversy exists regarding the need for $\mathrm{pH}$ control during fermentation, and in some cases are used buffered media for not having an adequate system of control. Nevertheless, studies had been identified an increase in the insecticidal activity of Bs (Yousten and Wallis, 1987) and Bti (Smith, 1982) when fermentation was performed without $\mathrm{pH}$ control.

The typical pattern for the change in $\mathrm{pH}$ in Bti cultivation reflects acid production in the first hours of culture from the use of glucose or others sugars. Then, $\mathrm{pH}$ gradually increases by the production of nitrogen compounds, reaching values close to 8.0 after about 30 hours and 9.0 after 50-60 hours of cultivation. In contrast, $\mathrm{pH}$ in the Bs fermentation increases gradually along the growth and spore formation, since there is no acid formation by the absence of sugars as a carbon source. In this case, an accumulation of ammonia is probably due to deamination of amino acids, and $\mathrm{pH}$ values are between 8.0 and 9.0, depending on the protein content in the culture medium.

In fed batch cultivation of Bti, the amount of sugar should not reach levels less than $2 \mathrm{~g} / \mathrm{L}$. Temperature should be maintained at $30^{\circ} \mathrm{C} \pm 2^{\circ} \mathrm{C}$; higher values inhibit toxins production while values below $25^{\circ} \mathrm{C}$ increase production costs.

Higher spores concentrations in $\mathrm{Bt}$ and $\mathrm{Bs}$ cultivations are required to obtain a high larvicidal activity, because sporulation is associated with the crystal toxic synthesis. However, high levels of sporulation are not always associated with a high toxicity of the crystals produced.

\subsection{Solid-liquid separation techniques}

About the product recovery step, the main interest in the production of biological insecticides is the cell mass and content of toxins. Thus, the main focus is solid-liquid separation. Removal of microbial cells is one of the most challenging problems in solidliquid separation. These particles having dimensions of the order of microns and low density, and often require pre-treatment to obtain efficient recoveries in the separation process by filtration or gravitational sedimentation, such as flocculation process.

In studies investigating the use of coagulants agents for cells recovery of Bs and Bti, it was observed that addition of electrolytes such as $\mathrm{CaCl}_{2} \cdot 2 \mathrm{H}_{2} \mathrm{O}, \mathrm{FeCl}_{3} \cdot 6 \mathrm{H}_{2} \mathrm{O}$ and $\mathrm{Al}_{2}\left(\mathrm{SO}_{4}\right)_{3}$ was efficient for cells recovery in concentrations ranging from 0.1 to $0.35 \mathrm{~g} / \mathrm{L}$ for recovery efficiencies above 95\%. Flocculation at $\mathrm{pH}$ between 2 and 4 promotes cellular aggregation for both bacteria. Characterization of flocculent suspensions demonstrated average diameter of flocs is dependent of the flocculated suspension (medium, $\mathrm{pH}$ ) and the mechanism of flocculating agent adsorption (electrolytes or $\mathrm{pH}$ changes) to cells. Overall, diameters were ranging from $103.1 \pm 4.3 \mu \mathrm{m}$ and $275.6 \pm 9.5 \mu \mathrm{m}$ to Bs and 162.2 $\pm 21.4 \mu \mathrm{m}$ and $313.9 \pm 21.9 \mu \mathrm{m}$ to Bti. Major values were corresponding to media containing suspended solids (LunaFinkler \& Finkler, 2008; Luna et al., 2003).

Addition of inorganic electrolytes can alter the charge properties of suspensions, making them unstable and causing the agglomeration of particles. Some factors influence the stability of colloidal dispersions, and therefore can determine the flocculation, such as electrolyte concentration (critical coagulation concentration), nature of the suspension, hydrolysis species in solution and ion valence of opposite charge to particles. Ions can act as 
electrolytes, reducing the electrostatic repulsion that usually exists between colloidal particles, or form bridges between them.

There are few studies about $\mathrm{pH}$ influence on the flocculation of bacteria. Luna et al. (2001), investigating the flocculation of $\mathrm{Bs}$, found that $\mathrm{pH} 3.0$ favored the aggregation and cells hydrophobicity. In general, most bacteria have a net negative charge on their surfaces, presenting isoelectric point in an acid medium. This is probably due to the large percentage of anionic groups, especially carboxyl and phosphate, to the detriment of cationic. Thus, the negatively charged surface allows interaction between cells and the protons in the environment, enabling the aggregation.

The observation that bacterial cells have a natural tendency to adhere to air bubbles during submerged and aerated fermentation processes suggests using the flotation for biomass recovery. The natural formation of foam is very common in these processes, due to the presence of protein in the original composition of the culture media or originated from the metabolism or cell lysis, either by production of surfactant substances during fermentation. This separation procedure is a technique well established in mineral technology and can be used for the recovery of various types of biological materials. The use of this process in the spores recovery of Bacillus genus is a promising alternative for obtaining bioactive concentrate, especially considering the hydrophobic nature of these cells.

Tests using a mechanical flotation cell showed spores recovery of Bs close to $100 \%$ for a flotation time of 5 minutes in the presence of a cationic collector and agitation of $960 \mathrm{rpm}$. Column flotation tests were performed in batch without addition of reagents, with a residual spores concentration of $2.5 \%$ after 30 minutes (Luna et al., 2005).

\subsection{Formulation}

Cells concentrated of the bacterial insecticide of genus Bacillus, after separated from their fermentation broths, are composed of a complex mixture of protoxins and spores. As proteins, protoxins are more sensitive to changes in their chemical structures and could be inactived by microbial contamination, ultraviolet radiation, proteolytic enzymes, sensitivity to temperature conditions, toxic compounds, uncontrolled drying or moisture.

These problems can be overcome by the development of appropriate techniques for product formulation. Formulated products increase efficiency in the field, are made for easy handling and application and allow lower-cost storage, reducing the loss in quality. However, there are few reports in the scientific literature on the study of formulations of entomopathogenic microorganisms, especially considering that formulations are generally kept confidential by the companies.

The components of a formulation should be inactive to the larvae and involve protoxins without increasing particle size (no more than $12 \mu \mathrm{m}$ ), otherwise could not be digested by the insect. Moreover, should contribute to increasing stability, virulence, efficacy and persistence of the biocontrol agent. Most pathogens of insects are highly susceptible to sunlight and require further protection methods to prolong its activity. It is essential to the improvement formulations based on entomopathogenic bacteria, especially research that characterizes relations between the components of a formulated (pathogen-adjuvant) and the factors that interfere with their production (temperature, humidity, etc.).

Formulations must also be compatible with the application techniques and existing equipments. In general, the application of microbial insecticides has been carried out with equipment and technology developed for chemical insecticides. Otherwise, would be difficult to compete in the market. Products based on entomopathogenic Bacillus can be 
liquid formulations, solids (wettable powders, dusts, water dispersible granules, encapsulated forms) and oil emulsions. A solid formulation has, in general, greater stability when compared to a liquid formulation, due to low moisture content, and also favors transportation and storage.

The first step in developing of a solid formulation is the powder preparation, which comprises the steps of drying and pulverizing the active ingredient. Determination of parameters as residual moisture, particle size distribution, angle of repose, flow time, volume and apparent and compacted density are indispensable for characterize the active powder.

For the encapsulated formulations, the choice of the encapsulating agent depends on the method of encapsulation, the type of product application and its mechanism of action. The rate of polymers hydrolysis depends on their chemical composition, the proportion of monomers and the particle size, and encapsulated cells may be released by mechanical stimuli (breaking pressure) or others, such as changes in temperature or $\mathrm{pH}$.

Methods employed for microencapsulation can be physical-chemical (evaporation/solvent extraction, phase separation or coacervation, liposome involvement), physical (spray drying, freeze drying, fluidized bed) and chemical (molecular inclusion, interfacial polymerization). The selection of preparation method depends on the properties of the polymer and the active ingredient.

The use of microcapsules for the development of microbial insecticides formulations has some advantages: protecting from adverse environmental conditions, increases shelf life of the product, controls the release, modifies undesirable properties of the active principle, form solid systems and releases the active ingredient in the desired location.

\section{Process on a laboratory scale to pilot-plant-fermenters}

In bioprocess development there are different operating conditions of bioreactors. Batch fermentation is currently used to Bacillus thuringiensis cultivation (Rivera et al., 1999; Silva et al., 2011; $\mathrm{Vu}$ et al., 2010). However, there are studies about cultivation in continuous (Selinger et al., 1988; Mignone \& Avignone-Rossa, 1996) and fed-batch (Jong et al., 1994; Jong et al., 1995; Jing-Wen et al., 2007) conditions. Also, cultivation in solid-state fermentation (Capalbo et al., 2001; Vimala-Devi et al., 2005) and pneumatic agitationaeration (air-lift) (Huang et al., 2001) has been recently investigated.

In all these processes control variables must be well established, mainly when the purpose is up-scaling fermentation processes from lab-scale to commercial units. Culture medium volume is increased and phenomena of mass transfer and energy become more complex. The main variables that influence on cell growth and metabolites production are $\mathrm{pH}$, temperature, dissolved oxygen (DO), composition of culture medium, oxygen transfer rate (OTR) and heat transfer rate (Hsu \& Wu, 2002). At large scale cultivation of Bacillus species it is critical to ensure that oxygen transfer and cooling capacity be adequate (Yang \& Wang, 1998). Other factors of relevance for scale up are quality of mixing, shear stress, selection of cheaper media, foam control, physiological state of the inoculum and sterilization of culture medium (Humphrey, 1998).

In scale-up of fermentation processes is essential to determine criteria and factors that reflect critical parameters on the process. For Bacillus fermentation, which is an aerobic bacterium, the most utilized criteria for scale-up is the correlation between the volumetric oxygen transfer coefficient $\left(\mathrm{K}_{\mathrm{La}}\right)$ and the volumetric airflow rate per unit volume $(\mathrm{Q} / \mathrm{V})$. Geometric 
similarities are another important factor, which represents the ratio between liquid height and vessel diameter or the ratio between impeller diameter and vessel diameter. This parameter is important from the practical point of view, because it simplifies prediction of large-scale fermentor performance (Ju \& Chase, 1992).

These concepts were adopted for some researchers in their studies. As the Bacillus cultivation occurs in aerobic conditions at $\mathrm{pH}$ and temperature defined, different strategies were established to scaling up. A general alternative observed in different studies is the use of renewable resources and readily available as raw materials for culture media composition. Moreover, also is possible make use of cultivation strategies to reduce the bioreaction time as inoculum volume, aeration rate and bioreactor design. Some examples of strategies adopted to increase yields in cellular mass and endotoxin production are presented at Table 2 .

\begin{tabular}{|c|c|c|c|c|}
\hline Objective & Strategy & Microrganism & Results & Reference \\
\hline $\begin{array}{l}\text { Formulation of } \\
\text { fermentation } \\
\text { media for } \\
\text { production of } \delta- \\
\text { endotoxins from } \\
\text { Bacillus } \\
\text { thuringiensis }\end{array}$ & $\begin{array}{l}\text { Leguminous seeds as } \\
\text { horse beans, kidney } \\
\text { beans, lima beans, } \\
\text { soybeans, chick peas, } \\
\text { lentils, and peanuts } \\
\text { were incorporated in } \\
\text { fermentation media } \\
\text { as sole proteins } \\
\text { sources for } \\
\text { biosynthesis of the } \\
\text { endotoxins. The } \\
\text { cotton pests, } \\
\text { Spodoptera littoralis, } \\
\text { Spodoptera exigua, and } \\
\text { Heliothis armigera } \\
\text { were used as test } \\
\text { insects for biological } \\
\text { assays }\end{array}$ & $\begin{array}{c}\text { Bacillus } \\
\text { thuringiensis } \\
\text { subsp. kurstaki } \\
\text { and entomocidus }\end{array}$ & $\begin{array}{l}\text { B. thuringienis } \\
\text { subsp. kurstaki } \\
\text { produced from } \\
\text { media containing } \\
\text { these nutrients } \\
\text { killed } 80-100 \% \text { of } \\
\text { H. armigera larvae } \\
\text { when tested at } \\
500 \mu \mathrm{g} / \mathrm{ml} \text { diet. }\end{array}$ & $\begin{array}{c}\text { Salama et al. } \\
\text { (1983) }\end{array}$ \\
\hline $\begin{array}{l}\text { Effect of media } \\
\text { formulation and } \\
\text { culture } \\
\text { conditions on } \\
\text { growth, } \\
\text { sporulation and } \\
\text { endotoxin } \\
\text { production }\end{array}$ & $\begin{array}{l}\text { Use of process } \\
\text { involving two } \\
\text { inoculum stages and } \\
\text { a } 48 \mathrm{~h} \text { production } \\
\text { stage in a } 40 \mathrm{~L} \\
\text { fermenter }\end{array}$ & $\begin{array}{c}\text { Bacillus } \\
\text { thuringiensis } \\
\text { subsp. israelensis }\end{array}$ & $\begin{array}{l}\text { The viable cell } \\
\text { count of } 6.5 \mathrm{x} \\
10^{9} / \mathrm{ml} \text { with } \\
\text { greater than } 95 \% \\
\text { sporulation }\end{array}$ & $\begin{array}{c}\text { Pearson \& } \\
\text { Ward } \\
\text { (1988) }\end{array}$ \\
\hline
\end{tabular}

Table 2. Studies about environmental conditions that have effect on the Bacillus cultivation processes. 


\begin{tabular}{|c|c|c|c|c|}
\hline Objective & Strategy & Microrganism & Results & Reference \\
\hline $\begin{array}{c}\text { Growth, } \\
\text { sporulation and } \\
\delta \text {-endotoxin } \\
\text { production in } \\
\text { oxygen limited } \\
\text { and non-limited } \\
\text { cultures } \\
\end{array}$ & \begin{tabular}{|c|} 
Production of \\
crystals and spores \\
was studied under \\
different aeration \\
conditions
\end{tabular} & $\begin{array}{c}\text { Bacillus } \\
\text { thuringiensis var } \\
\text { israelensis }\end{array}$ & $\begin{array}{c}\delta \text {-endotoxin yields } \\
\text { diminished under } \mathrm{O}_{2} \\
\text { limitation, suggesting } \\
\text { that toxin synthesis } \\
\text { mechanism could } \\
\text { have been affected. }\end{array}$ & $\begin{array}{l}\text { Avignone- } \\
\text { Rossa et al. } \\
\quad(1992)\end{array}$ \\
\hline $\begin{array}{c}\text { Cultivation in } \\
\text { an airlift reactor } \\
\text { with wire mesh } \\
\text { draft tubes }\end{array}$ & $\begin{array}{c}\text { An aeration } \\
\text { strategy was } \\
\text { proposed for foam } \\
\text { control in an airlift } \\
\text { reactor with double } \\
\text { wire mesh draft } \\
\text { tubes }\end{array}$ & $\begin{array}{c}\text { Bacillus } \\
\text { thuringiensis }\end{array}$ & \begin{tabular}{|c|} 
The production of \\
thuringiensin based \\
on the proposed \\
strategy was up to \\
$70 \%$ higher than that \\
of using the \\
conventional \\
cultivation method \\
with addition of \\
antifoam agents for \\
foam control \\
\end{tabular} & $\begin{array}{l}\text { Huang et al. } \\
\text { (2001) }\end{array}$ \\
\hline $\begin{array}{c}\text { Application of a } \\
\text { simple yeast } \\
\text { extract from } \\
\text { spent brewer's } \\
\text { yeast for } \\
\text { growth and } \\
\text { sporulation }\end{array}$ & $\begin{array}{c}\text { The suitability of } \\
\text { using a simple } \\
\text { brewer's yeast } \\
\text { extract (BYE), } \\
\text { prepared by } \\
\text { autolysis of } \\
\text { complete beer } \\
\text { slurry, was studied } \\
\text { in baffled shaken } \\
\text { flasks }\end{array}$ & $\begin{array}{c}\text { Bacillus } \\
\text { thuringiensis } \\
\text { subsp. kurstaki }\end{array}$ & \begin{tabular}{|} 
Growth in the \\
medium with a \\
commercial \\
laboratory-grade \\
yeast extract was \\
better than autolysed.
\end{tabular} & $\begin{array}{c}\text { Saksinchai et } \\
\text { al. (2001) }\end{array}$ \\
\hline $\begin{array}{l}\text { Effect of shear } \\
\text { stress for } \\
\text { thuringiensin } \\
\text { production }\end{array}$ & \begin{tabular}{|} 
Agitation speed \\
and aeration rate \\
were varied during \\
the exponential \\
growth phase and \\
stationary phase
\end{tabular} & $\begin{array}{c}\text { Bacillus } \\
\text { thuringiensis }\end{array}$ & $\begin{array}{c}\text { By decreasing the } \\
\text { agitation speed } \\
\text { during the stationary } \\
\text { phase, product } \\
\text { formation was } \\
\text { increased up to } 43 \% .\end{array}$ & $\begin{array}{l}\text { Wu et al. } \\
\text { (2002) }\end{array}$ \\
\hline $\begin{array}{l}\text { Barley-based } \\
\text { medium for the } \\
\text { cost-effective } \\
\text { production }\end{array}$ & \begin{tabular}{|} 
Using barley \\
Hordeum vulgare as \\
the carbon source \\
led to the \\
development of a \\
protocol for the \\
cost-effective, mass \\
production of Bt.
\end{tabular} & $\begin{array}{c}\text { Bacillus } \\
\text { thuringiensis }\end{array}$ & $\begin{array}{l}\text { Feeding cessation of } \\
\text { the larvae followed } \\
\text { by } 85 \% \text { and } 100 \% \\
\text { mortality by } 48 \text { and } \\
72 \text { h after treatment }\end{array}$ & $\begin{array}{l}\text { Vimala Devi } \\
\text { et al. (2005) }\end{array}$ \\
\hline
\end{tabular}




\begin{tabular}{|c|c|c|c|c|}
\hline Objective & Strategy & Microrganism & Results & Reference \\
\hline $\begin{array}{l}\text { Production of } \\
\text { mosquitocidal } \\
\text { Bacillus } \\
\text { sphaericus by } \\
\text { solid state } \\
\text { fermentation } \\
\text { using } \\
\text { agricultural } \\
\text { wastes } \\
\end{array}$ & $\begin{array}{c}\text { Twelve agricultural } \\
\text { wastes were tested } \\
\text { as the main carbon, } \\
\text { nitrogen and } \\
\text { energy sources } \\
\text { under solid state } \\
\text { fermentation }\end{array}$ & $\begin{array}{c}\text { Bacillus } \\
\text { sphaericus NRC } \\
69\end{array}$ & \begin{tabular}{|} 
Wheat bran was the \\
most efficient \\
substrate for the \\
production of $B$. \\
sphaericus \\
mosquitocidal toxins \\
against larvae of \\
Culex pipiens (LC C $_{50} 1.2$ \\
ppm)
\end{tabular} & $\begin{array}{l}\text { El-Bendary } \\
\text { (2010) }\end{array}$ \\
\hline $\begin{array}{c}\text { Development of } \\
\text { a cost-effective } \\
\text { medium for the } \\
\text { large scale } \\
\text { production }\end{array}$ & $\begin{array}{c}\text { Use soybean flour } \\
\text { (Glycine max), } \\
\text { groundnut cake } \\
\text { powder (Arachis } \\
\text { hypogea), and } \\
\text { wheat bran extract } \\
\text { (Triticum aestivum) }\end{array}$ & \begin{tabular}{|c|} 
Bacillus \\
thuringiensis var \\
israelensis (B.t.i.)
\end{tabular} & \begin{tabular}{|c|} 
Maximum toxicity \\
(LC C $_{50} 8.89 \mathrm{ng} / \mathrm{ml}$ \\
against Culex \\
quinquefasciatus IIIrd \\
instar larvae), \\
highest spore count \\
$\left(0.48 \times 10^{11}\right.$ c.f.u. $\left./ \mathrm{ml}\right)$, \\
and maximum \\
biomass $(7.8 \mathrm{~g} / \mathrm{L})$ \\
after $24 \mathrm{~h}$. \\
\end{tabular} & $\begin{array}{c}\text { Prabakaran \& } \\
\text { Balaraman } \\
(2006)\end{array}$ \\
\hline $\begin{array}{c}\text { Scale-up based } \\
\text { on oxygen } \\
\text { transfer }\end{array}$ & $\begin{array}{c}\text { Fermentation } \\
\text { process scale-up on } \\
\text { the basis of the } \\
\text { product } K_{\mathrm{L}} a \times \mathrm{p} \text {, } \\
\text { where } \mathrm{p} \text { is the } \\
\text { fermentor total } \\
\text { pressure }\end{array}$ & $\begin{array}{c}\text { Bacillus } \\
\text { thuringiensis }\end{array}$ & $\begin{array}{c}\text { Fermentation time } \\
\text { was decreased while } \\
\text { biomass yield and } \\
\text { sporulation efficiency } \\
\text { were unchanged }\end{array}$ & $\begin{array}{c}\text { Flores et al. } \\
\text { (1997) }\end{array}$ \\
\hline $\begin{array}{l}\text { Stirred tank for } \\
\text { ס-endotoxin } \\
\text { production: } \\
\text { mathematical } \\
\text { modelling and } \\
\text { scaling-up } \\
\text { studies }\end{array}$ & \begin{tabular}{|c|} 
Soya and molasses \\
were used in the \\
medium culture. \\
Aeration, agitation, \\
$\mathrm{pH}$ and molasses \\
initial \\
concentration were \\
chosen as \\
experimental \\
factors
\end{tabular} & $\begin{array}{c}\text { B. thuringiensis } \\
\text { H-14 }\end{array}$ & \begin{tabular}{|c|} 
The mathematical \\
model revealed that \\
the optimal batch \\
cultivation conditions \\
with respect to \\
agitation, pH, and \\
initial concentration \\
of molasses were 325 \\
rpm, 7.1 and $2.1 \%$ \\
$(\mathrm{w} / \mathrm{v})$, respectively.
\end{tabular} & $\begin{array}{l}\text { Abdel- } \\
\text { Hameed } \\
(2001)\end{array}$ \\
\hline $\begin{array}{c}\text { Scale-up of } \\
\text { biopesticide } \\
\text { production } \\
\text { processes using } \\
\text { wastewater } \\
\text { sludge as a raw } \\
\text { material } \\
\end{array}$ & \begin{tabular}{|} 
Use of shaken \\
flasks and two \\
geometrically \\
similar fermentors \\
(15 and 150 L)
\end{tabular} & $\begin{array}{c}\text { B. thuringiensis } \\
\text { var. kurstaki HD- } \\
1 \\
\text { (ATCC 33679) }\end{array}$ & $\begin{array}{c}\text { High productivity for } \\
\text { toxin protein yield } \\
\text { and high protease } \\
\text { activity. }\end{array}$ & $\begin{array}{c}\text { Yezza et al. } \\
\text { (2004) }\end{array}$ \\
\hline
\end{tabular}

Table 3. Studies about scale-up strategies to Bacillus cultivation. 
Concerning the large scale production, some researchers have developed studies about strategies to increase of the bioreactor size. For this, some variables should be considered. In the Table 3 are presented assays that use environmental conditions to proceed the bioprocess scale-up.

\section{Conclusion}

Bacteria of the genus Bacillus are among the most widely used entomopathogenic microorganisms, especially for its ability to form spores and toxins highly specific to target insects. Because they are spore-forming bacteria, are better suited to industrial production and field application, because they have less sensitivity to ultraviolet radiation and adverse weather conditions, increasing their persistence in the field.

Bacillus sphaericus and Bacillus thuringiensis are important agents utilized in insect control programs to reduce the population of disease vector species that transmit diseases such as malaria, yellow fever and dengue. Its cultivation of small scale production to pilot-plantfermenters requires knowledge about the stages of product development: storage and maintenance organisms, fermentation methods, solid-liquid separation techniques and formulations.

The process expansion on a laboratory scale to pilot-plant fermenters requires perform labscale experiments to support process changes and that the cost-benefit analysis is feasible. To achieve this purpose, studies have been developed using different strategies to defining the bioreactor design, the raw material used to compose the culture medium and cultivation conditions. Implementing scaling-up procedures is always a challenge; however, many nations are requiring the definition of working conditions for the cultivation of Bacillus species in large scale aiming application these organisms to remedy endemic diseases that affect the public health. For that, it is necessary the development of new technologies to expanding the commercial production to increase the availability of these products in the world market.

\section{Acknowledgment}

The authors are grateful to Conselho Nacional de Desenvolvimento Científico e Tecnológico (CNPq), Fundação de Amparo à Ciência e Tecnologia do Estado de Pernambuco (FACEPE) and Coordenação de Aperfeiçoamento de Pessoal de Ensino Superior (CAPES) for the financial support. This work is dedicated to memory of professor Giulio Massarani.

\section{References}

Abdel-Hameed, A. (2001) Stirred Tank Culture of Bacillus thuringiensis H-14 for Production of the Mosquitocidal $\delta$-endotoxin: Mathematical Modelling and Scaling-up Studies, World Journal of Microbiology and Biotechnology, Vol.17, No.9, (December 2001), pp. 857-861, ISSN: 0959-3993

Avignone-Rossa, C.; Arcas, J. \& Mignone, C. (1992) Bacillus thuringiensis Growth, Sporulation and $\delta$-endotoxin Production in Oxygen Limited and Non-limited Cultures, World Journal of Microbiology and Biotechnology, Vol.8, No.3, (May 1992), pp. 301-304, ISSN 0959-3993 
Baumann, P.; Clark, M.A.; Baumann, L. \& Broadwell, A.H. (1991). Bacillus sphaericus as a Mosquito Pathogen: Properties of the Organism and Its Toxins. Microbiology and Molecular Biology Reviews, Vol.55, No.3, (September 1991), pp. 425-436, ISSN $1092-$ 2172

Cannon, R.J.C. (1996) Bacillus thuringiensis Use in Agriculture: A Molecular Perspective, Biological Reviews, Vol.71, No.4, (November 1996), pp. 561-636, ISSN 1464-7931

Capalbo, D.M.F.; Valicente, F.H.; Moraes, I.O. \& Pelizer, L.H. (2001) Solid-state Fermentation of Bacillus thuringiensis tolworthi to Control Fall Armyworm in Maize, Electronic Journal of Biotechnology, Vol.4, No.2, (August 2001), pp. 112-115, ISSN 0717-3458

Charles, J.F.; Silva-Filha, M.H.; Nielsen-Leroux, C.; Humphreys, M.J. \& Berry, C. (1997) Binding of the 51- and 42-kDa Individual Components From the Bacillus sphaericus Crystal Toxin to Mosquito Larval Midgut Membranes From Culex and Anopheles sp. (Diptera: Culicidae). FEMS Microbiology Letters, Vol.156, No.1, (November 1997), pp. 153-159, ISSN 1574-6968

Couch, T.L. (2000). Industrial Fermentation and Formulation of Entomopathogenic Bacteria. In: Entomopathogenic Bacteria: From Laboratory to Field Application, J.F. Charles, A. Delécluse, C. Nielsen-LeRoux (Eds.), 297-314, Kluwer Academic Publishers, ISBN 0-7923-6523-2, Dordrecht, The Netherlands

Dias, J.M.C.S. (1992) Produção e Utilização de Bioinseticidas Bacterianos, Pesquisa Agropecuária Brasileira, Vol.27, (April 1992), pp. 59-76, ISSN 0100-204X

El-Bendary, M.A. (2010) Production of Mosquitocidal Bacillus sphaericus by Solid State Fermentation Using Agricultural Wastes, World Journal of Microbiology and Biotechnology, Vol.26, No.1, (January 2010) pp. 153-159, ISSN 0959-3993

Flores, E.R.; Pérez, F. \& de la Torre, M. (1997) Scale-up of Bacillus thuringiensis Fermentation Based on Oxygen Transfer, Journal of Fermentation and Bioengineering, Vol.83, No.6, pp. 561-564, ISSN 0922-338X

Goldberg, L.J. \& Margalit, J.A. (1977) A Bacterial Spore Demonstrating Rapid Larvicidal Activity Against Anopheles sergentii, Uranotaenia unguiculsts, Culex univiattus, Aedes aegypti and Culex pipiens, Mosquito News, Vol.37, No.3, (September 1977), pp. 355358, ISSN 0027-142X

Honée, G. \& Visser, B. (1993) The Mode of Action of Bacillus thuringiensis Crystal Proteins, Entomologia Experimentalis et Applicata, Vol.69, No.2, (November 1993), pp. 145-155, ISSN 1570-7458

Hongyu, Z.; Ziniu, Y. \& Wangxi, D. (2000) Isolation, Distribution and Toxicity of Bacillus thuringiensis from Warehouses in China, Crop Protection, Vol.19, No.7, (August 2000), pp. 449-454, ISSN 0261-2194

Hsu, Y.L. \& Wu, W.T. (2002) A Novel Approach for Scaling-up a Fermentation System. Biochemical Engineering Journal, Vol.11, No.2-3, (September 2002), pp. 123-130, ISSN 1369-703X

Huang, T.K., , Wang, P.M. \& Wu, W.T. (2001) Cultivation of Bacillus thuringiensis in an Airlift Reactor with Wire Mesh Draft Tubes, Biochemical Engineering Journal, Vol. 7, No. 1, (January 2001), pp. 35-39, ISSN 1369-703X

Humphrey, A (1998) Shake Flasks to Fermentor: What Have We Learned? Biotechnology Progress, Vol.14, No.1, (January 1998), pp. 3-7, ISSN 1520-6033

Jing-Wen, Z.; Ya-Fei, C.; Zheng-Hong, X.; Zi-Niu, Y. \& Shou-Wen, C. (2007) Production of thuringiensin by Fed-batch Culture of Bacillus thuringiensis subsp. darmstadiensis 032 with an Improved $\mathrm{pH}$-control Glucose Feeding Strategy, Process Biochemistry, Vol.42, No.1, (January 2007), pp. 52-56, ISSN: 1359-5113 
Jong, J.Z.; Wu, W.T. \& Tzeng, Y.M. (1994) pH Control for Fed-batch Culture of Bacillus thuringiensis, Biotechnology Techniques, Vol.8, No.7, (July 1994), pp. 483-486, ISSN 0951-208X

Jong, J.Z.; Hsiun, D.Y.; Wu, W.T.; Tzeng, Y.M. (1995) Fed-batch Culture of Bacillus thuringiensis for thuringiensin Production in a Tower Type Bioreactor, Biotechnology and Bioengineering, Vol.48, No.3, (November 1995), pp. 207-213, ISSN1097-0290

Ju, L.K. \& Chase, G.G. (1992) Improved Scale-up Strategies of Bioreactors. Bioprocess and Biosystems Engineering, Vol.8, No.1-2, (October 1992), pp. 49-53, ISSN 1615-7591

Kellen, W.R.; Clark, T.B.; Lindegren, J.E.; Ho, B.C.; Rogoff, M.H. \& Singer, S. (1965) Bacillus sphaericus Neide as a Pathogen of Mosquitoes, Journal of Invertebrate Pathology, Vol.7, No.4, (December 1965), pp. 442-448, ISSN 0022-2011

Kumar, P.A.; Sharma, R.P. \& Malik, V.S. (1996) the Insecticidal Proteins of Bacillus thuringiensis, Advances in Applied Microbiology, Vol.42, pp. 1-43, ISBN 9780120026425

Luna, C.L.; Silva, G.R. \& Rios, E.M.M.M. (2004) Bacillus thuringiensis var. israelensis Production Involving Re-use of the Supernatant, Biotechnology Letters, Vol.26, No.2, (January 2004), pp. 143-145, ISSN 1573-6776

Luna, C.L.; Rios, E.M.M. \& Lopes, C.E. (2001) On the Settling of Bacillus sphaericus Spores by pH Adjustment, Biotechnology Letters, Vol.23, No.12, (June 2001), pp. 1011-1013, ISSN 1573-6776

Luna, C.L.; Lopes, C.E. \& Massarani, G. (2003) Recovery of Bacillus sphaericus 2362 Spores from Growth Medium by Flocculation/Sedimentation, Bioprocess and Biosystems Engineering, Vol.25, No.4, (January 2003), pp. 213-216, ISSN 1615-7605

Luna, C.L.; Lopes, C.E. \& Massarani, G. (2005) Recovery of Bacillus sphaericus Spores by Flocculation/Sedimentation and Flotation, Brazilian Archives of Biology and Technology, Vol.48, (June 2005), pp. 61-70, ISSN 1516-8913

Luna-Finkler, C.L. \& Finkler, L. (2008) Production of Concentrates of Bacterial Bioinsecticide Bacillus thuringiensis var. israelensis by Flocculation/Sedimentation, Acta Tropica, Vol.107, No.2, (August 2008), pp. 134-138, ISSN 0001-706X

Mignone, C.F. \& Avignone-Rossa, C. (1996) Analysis of Glucose Carbon Fluxes in Continuous Cultures of Bacillus thuringiensis, Applied Microbiology and Biotechnology, Vol.46, No.1, (August 1996), pp. 78-84, ISSN 0175-7598

Navon, A. (2000) Bacillus thuringiensis Insecticides in Crop Protection - Reality and Prospects, Crop Protection, Vol.19, No.8-10, (September 2000), pp. 669-676, ISSN 0261-2194

Pearson, D. \& Ward, O. P. (1988) Effect of Culture Conditions on Growth and Sporulation of Bacillus thuringiensis subsp. israelensis and Development of Media for Production of the Protein Crystal Endotoxin, Biotechnology Letters, Vol.10, No.7, (July 1988), pp. 451-456, ISSN 1573-6776

Prabakaran, G. \& Balaraman, K. (2006) Development of a Cost-effective Medium for the Large Scale Production of Bacillus thuringiensis var israelensis, Biological Control, Vol.36, No.3, (March 2006), pp. 288-292, ISSN: 1049-9644

Rivera, D.; Margaritis, A. \& Lasa, H. (1999) A Sporulation Kinetic Model for Batch Growth of B. thuringiensis, The Canadian Journal of Chemical Engineering, Vol.77, No.5, (October 1999), pp. 903-910, ISSN 1939-019X

Rukmini, V.; Reddy, C.Y. \& Venkateswerlu, G. (2000) Bacillus thuringiensis Crystal $\delta$ endotoxin: Role of Proteases in the Conversion of Protoxin to Toxin, Biochimie, Vol.82, No.2, (February 2000), pp. 109-116, ISSN 0300-9084

Russel, B.L.; Jelley, S.C. \& Yousten, A.A. (1989) Carbohydrate Metabolism in the Mosquito Pathogen Bacillus sphaericus 2362, Applied and Environmental Microbiology, Vol.55, No.2, (February 1989), pp. 294-297, ISSN 0099-2240 
Salama, H.S.; Foda, M.S.; Dulmage, H.T. \& El-Sharaby, A. (1983) Novel Fermentation Media for Production of $\delta$-endotoxins from Bacillus thuringiensis, Journal of Invertebrate Pathology, Vol.41, No.1, (January 1983), pp. 8-19, ISSN: 0022-2011

Selinger, L.B.; Dawson, P.S.S. \& Khachatourians, G.G. (1988) Behavior of Bacillus thuringiensis var. kurstaki Under Continuous Phased Cultivation in a Cyclone Fermentor, Applied Microbiology and Biotechnology, Vol.28, No.3, (May 1988), pp. 247253, ISSN 0175-7598

Saksinchai, S.; Suphantharika, M. \& Verduyn, C. (2001) Application of a Simple Yeast Extract from Spent Brewer's Yeast for Growth and Sporulation of Bacillus thuringiensis subsp. kurstaki: a Physiological Study, World Journal of Microbiology and Biotechnology, Vol.17, No.3, (April 2001), pp. 307-316, ISSN: 0959-3993

Silva, M.; Furigo Junior, A.; Furlan, S.A. \& Souza, O. (2011) Production of Bio-inseticide Bacillus thuringiensis var. israelensis in Semicontinuous Processes Combined With Batch Processes for Sporulation, Brazilian Archives of Biology and Technology, Vol.54, No.1, (January/February 2011), pp. 45-52, ISSN 1516-8913

Singer, S. (1973) Insecticidal Activity of Recent Bacterial Isolates and Their Toxins Against Mosquito Larvae, Nature, Vol.244, No.5411, (July 1973), pp. 110-110, ISSN 0028-0836

Smith, R.A. (1982) Effect of Strain and Medium Variation on Mosquito Toxin Production by Bacillus thuringiensis serovar. israelensis, Canadian Journal Microbiology, Vol.28, No.9, (September 1982), pp. 1089-1092, ISSN 0008-4166

Vimala Devi, P.S.; Ravindera, T. \& Jaideva, C. (2005) Cost-effective Production of Bacillus thuringiensis by Solid-state Fermentation, Journal of Invertebrate Pathology, Vol.88, No.2, (February 2005), pp. 163-168, ISSN 0022-2011

Vontersch, M.A.; Slatin, S.L.; Kulesza, C.A. \& Eglish, G.H. (1994) Membrane Permeabilising Activities of Bacillus thuringiensis Cry IIIB2 and Cry IIIB2 Domain I Peptide, Applied and Environmental Microbiology, Vol.60, No.10, (October 1994), pp. 3711-3717, ISSN 0099-2240

Vu, K.D.; Tyagi, R.D.; Valéro J.R. \& Surampalli, R.Y. (2010) Batch and Fed-batch Fermentation of Bacillus thuringiensis Using Starch Industry Wastewater as Fermentation Substrate, Bioprocess Biosystem Engineering, Vol.33, No.6, (August 2010), pp.691-700, ISSN 1615-7591

Weiser, J.A. (1984) A Mosquito-Virulent Bacillus sphaericus in Adult Simulium damnosum From Northen Nigeria, Zentralbatt fur Mikrobiologie, Vol.139, No.1, (January 1984), pp. 57-60, ISSN 0232-4393

Wu, W.T.; Hsu, Y.L.; Ko, Y.F. \& Yao, L.L. (2002) Effect of Shear Stress on Cultivation of Bacillus thuringiensis for thuringiensin production, Applied Microbiology and Biotechnology, Vol.58, No.2, (January 2002), pp. 175-177, ISSN 0175-7598

Yang, X.M. \& Wang, S.S. (1998) Development of Bacillus thuringiensis Fermentation and Process Control from a Practical Perspective, Biotechnology Applied Biochemistry, Vol.28, No.2, (October 1998), pp. 95-98, ISSN 1470-8744

Yezza, A.; Tyagi, R.D.; Valero, J.R.; Surampalli, R.Y.; Smith, J. (2004) Scale-up of Biopesticide Production Processes Using Wastewater Sludge as a Raw Material, Journal of Industrial Microbiology and Biotechnology, Vol. 31, No.12 (November 2004), pp. 545552, ISSN 1367-5435

Yousten, A.A. \& Wallis, D.A. (1987) Batch and Continuous Culture of the Mosquito Larval Toxin of Bacillus sphaericus 2362, Journal of Industrial Microbiology \& Biotechnology, Vol.2, No.5, (December 1987), pp. 277-283, ISSN 1367-5435 


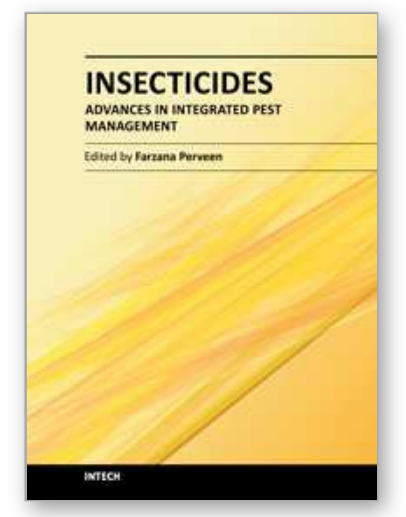

\author{
Insecticides - Advances in Integrated Pest Management \\ Edited by Dr. Farzana Perveen
}

ISBN 978-953-307-780-2

Hard cover, 708 pages

Publisher InTech

Published online 05, January, 2012

Published in print edition January, 2012

This book contains 30 Chapters divided into 5 Sections. Section A covers integrated pest management, alternative insect control strategies, ecological impact of insecticides as well as pesticides and drugs of forensic interest. Section B is dedicated to chemical control and health risks, applications for insecticides, metabolism of pesticides by human cytochrome p450, etc. Section $\mathrm{C}$ provides biochemical analyses of action of chlorfluazuron, pest control effects on seed yield, chemical ecology, quality control, development of ideal insecticide, insecticide resistance, etc. Section $D$ reviews current analytical methods, electroanalysis of insecticides, insecticide activity and secondary metabolites. Section E provides data contributing to better understanding of biological control through Bacillus sphaericus and B. thuringiensis, entomopathogenic nematodes insecticides, vector-borne disease, etc. The subject matter in this book should attract the reader's concern to support rational decisions regarding the use of pesticides.

\title{
How to reference
}

In order to correctly reference this scholarly work, feel free to copy and paste the following:

Christine Lamenha Luna-Finkler and Leandro Finkler (2012). Bacillus sphaericus and Bacillus thuringiensis to Insect Control: Process Development of Small Scale Production to Pilot-Plant-Fermenters, Insecticides Advances in Integrated Pest Management, Dr. Farzana Perveen (Ed.), ISBN: 978-953-307-780-2, InTech, Available from: http://www.intechopen.com/books/insecticides-advances-in-integrated-pestmanagement/bacillus-sphaericus-and-bacillus-thuringiensis-to-insect-control-process-development-of-smallscale-

\section{INTECH}

open science | open minds

\section{InTech Europe}

University Campus STeP Ri

Slavka Krautzeka 83/A

51000 Rijeka, Croatia

Phone: +385 (51) 770447

Fax: +385 (51) 686166

www.intechopen.com

\section{InTech China}

Unit 405, Office Block, Hotel Equatorial Shanghai

No.65, Yan An Road (West), Shanghai, 200040, China 中国上海市延安西路65号上海国际贵都大饭店办公楼 405 单元

Phone: +86-21-62489820

Fax: +86-21-62489821 
(C) 2012 The Author(s). Licensee IntechOpen. This is an open access article distributed under the terms of the Creative Commons Attribution 3.0 License, which permits unrestricted use, distribution, and reproduction in any medium, provided the original work is properly cited. 